\title{
JOHN AUSTIN E OS ATOS DE FALA
}

\section{[John Austin and the Speech Acts]}

Prof. Fernando Castim

Prof. Titular do Dep. De Letras UNICAP

\begin{abstract}
This work aims to study Speech Acts according to John L. Austin, Searle, Wittgenstein and others who studied the language is not only a process of communication, but specialy a way to do things with words, according to Austin. Must of examples were taken from the Gospels in New Testament.

Keywords: acts, words, performatives, Austin.

Resumo: O presente texto objetiva realizar uma análise a partir da teoria dos atos de fala de J. L. Austin, Searle, Wittgenstein e outros pensadores que estudam a linguagem e não apenas o processo de comunicação, para especificamente mostrara como se pode utilizar a linguagem de acordo com Austin, principalmente. Muitos dos exemplos foram retirados dos evangelhos no Novo Testamento.

Palavras-Chaves: atos, palavras, performance, Austin.
\end{abstract}

\section{INTRODUÇÃO}

Durante muitos séculos, a linguagem humana e, obviamente, as línguas foram objeto de investigação movida mais pela curiosidade do que pelo interesse científico. Até mesmo o sagrado motivou o estudo do sânscrito na Índia. Na Grécia de Platão e Aristóteles, especulava-se a origem dos nomes: o significado da palavra estava ligado às coisas por uma relação natural ou convencional? Daí o Realismo e o Nominalismo, que perpassam também pelos autores medievais. Já no pós-renascimento, há um interesse voltado para a pesquisa filológica, ou seja, a ciência procura fazer um estudo comparado das línguas indo-europeias, cujo mérito foi abrir um campo vasto e fecundo na história das línguas. Estudiosos como Bopp e Grimm legaram-nos um método na pesquisa diacrônica. Já posteriormente, surgiram os neogramáticos, que se limitaram a classificar os fenômenos linguísticos sem, contudo, esclarecê-los. Estavam apegados às normas rígidas da Fonética e da Analogia. Enfim, chegou Ferdinand de Saussure, o marco inicial da linguística moderna, o divisor de águas entre as pesquisas diacrônicas (Comparativismo) e a moderna ciência da linguagem - a Linguística. 
Para Borba (1975), Saussure deu notável impulso à Linguística através de suas pesquisas sobre problemas gerais da linguagem. Sua doutrina está no seu "Curso de Linguística Geral", obra resultante das anotações de aulas dos seus alunos Bally e Sechehaye da Universidade de Paris. Publicada em 1916, alguns anos após a morte do mestre de Genebra.

Os conceitos de Saussure que tornaram a sua obra o ponto de partida para os estudos da linguística moderna foram os de "língua $x$ fala", "significante $x$ significado", "sincronia $x$ diacronia", "sintagma $x$ paradigma".

\section{TEMPOS MODERNOS NA LINGUÍSTICA: A TEORIA DOS ATOS DE FALA}

Para Saussure, o signo linguístico possui um lado mental e um lado social, visto que sempre forma um sistema inserido dentro de uma sociedade. A primeira visão do signo é a de que ele sempre expressa ideias - conceitos, significados, afecções da alma - internamente residentes na mente de cada membro de uma sociedade. Mas o signo não pode ser visto apenas como uma abstração: para Marcondes (2017), “a linguagem seria o mais importante dos vários sistemas de signos devido a sua complexidade e a sua maior capacidade de significar.(...) daí, a dupla função: a exteriorização de algo interior e o uso social, a interação."

Para a filosofia da linguagem, os nomes são verdadeiros invólucros para as coisas nomeadas. Disso podemos inferir a diferença dos nomes para os sinais naturais. Ambos remetem para algo fora de si mesmos; os signos linguísticos, porém, só têm sua razão de ser enquanto elemento de um sistema, uma cultura. Assim, os signos linguísticos pressupõem sempre os seus usuários e são constituídos por eles e para eles.

Modernamente, herdamos o impasse sobre a natureza convencional do signo desde Platão, em "Crátilo". Hermógenes e Crátilo continuam a discutir mediados por Sócrates, como está estruturado na obra de Platão. Kant nos aponta uma nova caracterização do conceito como regra para determinação do objeto (Marcondes, 2017). "Encontramos na "Analítica dos conceitos" da Crítica da razão pura justamente a tese da prioridade do juízo - dotado de uma estrutura lógica - sobre o conceito. Para Kant, o conceito é sempre o predicado de um juízo possível'”. (Marcondes, 2017)

Os filósofos de tradição analítica, como Russel e Wittgenstein, procuraram uma concepção de linguagem mais voltada para uma estrutura lógica. O estudo do 
significado parte agora de uma estrutura lógica - a sentença - correspondente na realidade a uma estrutura ontológica, como afirma Danilo Marcondes (2017).

A partir dos anos 1940, desenvolveu-se uma outra teoria na concepção da linguagem. Wittgenstein e Austin veem a ciência agora como uma das formas possíveis na relação com o real. "A linguagem passa a ser vista como uma prática social e examinada sempre a um contexto de uso. " (Idem). Daí os chamados jogos de linguagem, que valorizam a prática concreta do caráter interativo e intersubjetivo da linguagem. Falante e ouvinte interagem de acordo com o contexto e os usos da linguagem. De acordo com Marcondes:

A semântica dá lugar à pragmática, isto é, à consideração da linguagem como uso, como práxis, nas palavras de Wittgenstein em Investigações filosóficas (§7).)

Já John Austin, em Quando dizer é fazer (How to do things with words) apresenta a noção de ato de fala valorizando

o uso concreto da linguagem e enfatizando o seu caráter prático. É assim que, para Austin, dizer "eu prometo" não é realizar uma intenção de prometer nem descrever uma atitude mental, mas realizar a promessa. A linguagem tem, pois, segundo essa concepção, um caráter performativo, pois é por meio dela que realizamos uma série de atos, como prometer, ordenar, pedir, eleger, nomear todos verbos performativos.

Decorrente do que pregam os filósofos da pragmática, o significado decorre do uso ou das possibilidades de uso da linguagem, ou de regras que determinam o uso do possível e não mais de objetos na sua perspectiva de realidade. A partir de agora, a análise dos elementos contextuais objetivam o conhecimento dos pressupostos dos efeitos e das consequências do uso para a determinação do significado. Para a reconstrução do significado.

Recentes teorias, como dos alemães Apel e Habermas, tomam como base o caráter contratual que a linguagem pressupõe. Afinal de contas, quando proferimos determinadas sentenças ${ }^{\mathrm{i}}$, colocamos em adjunto o fato de que há sempre no que dizemos algo de promessa e compromisso que assumimos perante nosso interlocutor. Ou como afirmam os autores: não apenas prometemos cumprir o que fazemos, mas procuramos gerar na pessoa ou pessoas certas expectativas, em nome das quais pode ou podem exigir o cumprimento da promessa. Tal teoria reafirma Saussure na sua concepção de 
que a língua é um ser social por excelência. A teoria dos atos de fala se assenta num conceito social: o uso, a promessa, o fazer.

\section{1. - OS ATOS PERFORMATIVOS}

Performativo é o ato produzido que realiza o ato que está sendo enunciado. É interessante o exemplo que Victoria Wilson ${ }^{\mathrm{ii}}$ nos dá: Ajoelhou tem que rezar.

Para Austin, dizer algo equivale a três atos simultâneos:

o ato locutório: baseado nos níveis fonético, sintático e referencial. Baseado no conteúdo linguístico usado para dizer algo;

o ato ilocutório: é o ato central; para Austin, é aquele que tem a força performativa. Associado ao modo de dizer e ao modo como esse dizer é recebido em função da força proferido;

o ato perlocutório: equivale aos efeitos causados sobre o outro, servindo a outros fins, como influenciar o outro, persuadi-lo a fazer algo, causar um embaraço ou constrangimento. ${ }^{\text {iii }}$

Há uma classificação adotada por Searle ${ }^{\mathrm{iv}}$ dos atos performativos:

1- Atos assertivos: são aqueles que se usam para representar fatos ou situações que o interlocutor pode comprovar. Por isso o critério de reconhecimento de um ato de fala como asserção é apurar se a predicação atribuída a um certo objeto de conhecimento lhe corresponde ou não. ( Ex: As árvores florescem na primavera. Graciliano Ramos nasceu em Palmeiras dos Índios.) A propósito de cada um se pode dizer se é falso ou verdadeiro.

2- Atos diretivos: são aqueles que dão ao interlocutor indicações para proceder de uma determinada maneira. São diretivos tanto os atos expressos com frases interrogativas e imperativas. (És maior de dezoito anos? Guarde esse segredo com você.)

3- Atos compromissivos: são os que revelam um compromisso/disposição ao enunciadpor em nagir ou proceder em conformidade com o conteúdo proposicional da frase. Tais atos podem ser realizados no interesse ou 
prejuízo do interlocutor, dai a distinção entre promessas (Amanhã eu lhe telefono, sem falta) e ameaças (Essa ofensa não vai ficar assim).

4- Atos expressivos: tais atos verbalizam congratulações, discursos, condolências.

5- Declarativos: são atos por meio dos quais se cria ou se modifica um estado de coisas no mundo. Findo o julgamento, o juiz profere a sentença: Absolvo o réu da acusação que lhe imputam. O menino abre a gaiola e diz ao pássaro: "Você está livre" Nas duas situações. A frase tem o poder de criar uma situação ou mudá-la: "A inocência do réu." "A liberdade de um pássaro.”

6- Atos interjetivos: referem-se a palavras ou palavra (frase de situação), realizando típicos atos de fala diretivos ou expressivos.

Para Searle (1984, p 44), existe um marcador de força ilocucional, que, em português pode ser expresso nos seguintes processos: a ordem das palavras, o acento tônico, a entoação, a pontuação, o modo do verbo e o uso dos verbos performativos. Mas adverte o autor que, no discurso, é o contexto que permitirá fixar a força ilocucional da enunciação, sem que haja necessidade de recorrer ao marcador explícito apropriado. (Searle, 1984)

\subsection{AINDA SOBRE A PRAGMÁTICA}

Segundo José Luiz Fiorin (2015), a pragmática estuda a relação entre a linguagem e seu uso, o que fora deixado de lado pelo estruturalismo Saussureano. Sem dúvida, o estudo do uso se faz necessário, "pois há palavras e frases cujo interpretação só pode ocorrer na situação concreta da fala.

"Quando se diz a alguém: "Você sabe onde fica a av. Tiradentes?, não se está perguntando se ele conhece a cidade, mas se está pedindo que explique onde fica essa via pública. Seria bizarro que a pessoa respondesse pura e simplesmente "SEI" e não se pusesse a explicar a localização da avenida". (FIORIN, JOSÉ LUIZ.Linguística? Que é isso? S. Paulo: Contexto, 2015, p 82) 
Para o autor acima citado e já o óbvio na linguística, a distinção entre língua e fala, entre o virtual e o realizado, cada indivíduo realiza seus atos de fala. Daí, a língua ser o lado social da linguagem e a fala o seu aspecto concreto e individual, o seu reino da criação e da liberdade. Sendo assim, a enunciação é a instância do ego, hic et nunc (eu, aqui e agora, em latim). Essa instância é universal, o que significa que ela está presente em todas as línguas naturais, como o inglês, o turco, o russo e o francês e mesmo em todas as linguagens, como a linguagem virtual do cinema e da pintura. As categorias de pessoa, tempo e espaço só ganham sentido na enunciação, porque o eu se constitui quando alguém toma a palavra, já que ele indica quem fala; o tu é aquele a quem ele se dirige; aqui é o lugar em que o eu fala; e o agora é o momento da fala (Cf Benveniste, 1976: 247-83)

Benveniste, citado por Fiorin et al (2015), distingue a língua do seu exercício. Tal exercício não é uma virtualidade, mas uma realidade. O que permite a passagem do virtual para o real é a enunciação, que é a colocação em funcionamento da língua por um ato de fala. A enunciação é a instância que permite a passagem da língua para a fala, é uma instância mediadora entre a língua e a fala. Tal instância é um conjunto de categorias que permite essa passagem da língua à fala. Essas categorias são a pessoa, o tempo e o espaço. A enunciação é a instância do ego, do hic et nunc, que está presente em todas as línguas. Tais categorias ganham sentido na enunciação (Fiorin, 2015). Já para Saussure, a maior unidade que ocupava esta ciência era o período, formado por uma ou mais orações. Agora, com os novos estudos, a unidade sobre a qual se debruça a linguística é o texto, manifestação do discurso.

\section{3 - AINDA É BOM LEMBRAR SOBRE A PRAGMÁTICA}

\section{Classificação dos Efeitos dos Atos da Fala}

Austin divide os atos da fala em três partes:

Ato locutório: ato de pronunciar um enunciado com mensagem que ouvinte (interlocutor) compreende [2]. Em outras palavras é o que eu digo.

Ato ilocutório: ato que o realizado pelo locutor quando pronuncia um enunciado em determinadas condições comunicativas e 
com intenções (ordenar, avisar, criticar, perguntar, convidar, ameaçar, etc.) Num ato ilocutório, a intenção comunicativa de execução vem associada ao significado de determinado enunciado, e a ação do ouvinte (interlocutor) [2]. Em outras palavras é o que eu quero que o interlocutor faça.

Ato perlocutório: corresponde aos efeitos que um dado ato ilocutório produz no interlocutor. Verbos como convencer, persuadir ou assustar ocorrem neste tipo de atos de fala, pois informam-nos do efeito causado no interlocutor [2]. Em outras palavras é o que o interlocutor faz.

O professor Michael Drout, menciona a estória do Rei Inglês Henrique II, que em uma conversa disse: "Quem vai me livrar deste padre intrometido?", alguns soldados ouviram e mataram o tal padre. Esta foi a força perlocutória do ato, embora a intenção do Rei não fosse que o padre fosse de fato morto. A princípio, era um ato nãoperformativo, mas acabou por se tornar um ato performativo. (Disponível em: http//www.recanto das letras.com.br/2172890. Acesso em 02 de maio de 2017)

\section{ANÁliSE DE ATOS DE FALA NOS EVANGELHOS: O ENUNCIADO PERFORMATIVO EM JESUS CRISTO}

Como já foi visto acima, o enunciado performativo não descreve, não relata nem constata absolutamente nada (nem são falsos nem verdadeiros). Mais precisamente, são enunciados produzidos da $3^{a}$ pessoa do singular, na forma afirmativa e na voz ativa, eles realizam uma ação. Reexemplificando o já explicado: "Eu te batizo em nome do Pai, do Filho e do Espírito Santo; Eu te condeno a dez meses de trabalho comunitário; Ordeno que você saia; Eu te perdoo; Declaro aberta a sessão. Tais enunciados, no exato momento em que são proferidos, realizam a ação denotada pelo verbo. “

Por outro lado, saliente-se que, para um enunciado ser bem sucedido, ou seja, para que a ação expressa por ele seja de fato realizada, é preciso, ainda, que as circunstâncias sejam adequadas. Um enunciado pronunciado em circunstâncias inadequadas nem é falso nem verdadeiro, mas sim nulo, sem efeito. Ele simplesmente fracassa, Assim, por exemplo, se um faxineiro (e não o presidente da câmara) diz 
Declaro aberta a sessão, o performativo não se realiza, a sessão não se abre, porque o faxineiro carece de autoridade para abrir a sessão. O enunciado é, portanto, nulo, sem efeito.

Note-se também que Austin propõe algumas diretrizes para que um enunciado seja performativo.

1- Nem todo enunciado performativo tem verbo na $1^{\mathrm{a}}$ pessoa. Exs: É proibido fumar; Vocês estão autorizados a sair.

2- em todo enunciado na primeira pessoa do singular do presente do indicativo, na forma afirmativa e na voz ativa é performativo. Exs: Eu jogo futebol; Eu corro; Eu estudo inglês.

3- Austin constatou que pode haver enunciado performativos sem nenhuma palavra relacionada ao ato que executam. Exs: Curva perigosa; Virei amanhã.

Entenda-se: Em "Curva perigosa" = Eu te advirto que a curva é perigosa; Feche a porta $=$ Eu te ordeno que feche a porta.

Austin ainda chega à conclusão de que todo ato de fala é ao mesmo tempo locucionário, ilocucionário e perlocucionário. No enunciado "Eu prometo que estarei em casa hoje à noite, há o enunciado", há o ato de enunciar cada elemento linguístico que compõe a frase (ato locucionário). Paralelamente em que se enuncia essa frase, realiza-se $\mathrm{o}$ ato de promessa (ato ilocucionário. Quando se enuncia essa frase, o resultado pode ser de ameaça, de agrado ou de desagrado (perlocutório) um ato que não se realiza na linguagem, mas pela linguage. (Disponível em: http://www.Austin e a a teoria dos atos de fala.com.br Acesso em 03 de maio de 2017)

\section{APLICAÇÕES EM TEXTOS EVANGÉLICOS}

\section{1- Joao dirigiu-se a todos: "Eu vos batizo com água..” (Lucas 3, 16)}

Eis a relação de João Batista com o Messias, uma relação de oposição, ou seja, o Batista exerce um batismo de penitência com água, mas o que vai chegar os batizará com o fogo e com o Espírito de Deus. Sente-se a segurança de João através do ato performativo, reforçado pela expressão ilocutória. 


\section{2- Jesus cura um leproso: "Quero, fica curado.”}

O ato de Jesus Cristo se manifesta sobretudo no verbo performativo “Eu quero”. Ao proferir a sentença, o homem ficou curado. Não se pode afirmar com certeza que era lepra. Poderia ser uma das muitas doenças de pele que assolavam aquela região desértica e insalubre. De qualquer forma, ele volta ao convívio social por meio do ato de Cristo e, posteriormente, ao apresentar-se aos sacerdotes.

3- Jesus cura o homem que tinha a mão paralisada: “- Levanta-te e te põe de pé no meio. Eles se pôs de pé. Depois se dirigiu a eles: - Eu vos pergunto o que é permitido no sábado: fazer o bem ou o mal...” (...) Depois, olhando a todos a sua volta, disse ao homem: - Estende a mão. E o fez e a mão ficou restabelecida."

A força das palavras de Jesus se manifesta não só pela sua divindade como também pelos atos performativos, pelos quais, segundo Austin: “o dizer é fazer”. A força ilocucionária se manifesta também pelos verbos no imperativo.

4- Jesus ressuscita o filho da viúva. "Justamente quando se aproximava da porta da cidade, levavam para fora um morto, filho único de uma viúva; acompanhava-a um grupo de moradores. Ao vê-la (Jesus) sentiu compaixão e disse: - Não chores. Aproximou-se, tocou o féretro, e os carregadores pararam. Então disse: - Jovem, falo contigo, levanta-te. O morto se levantou e começou a falar. Jesus o entregou a sua mãe."

Novamente, os milagres de Jesus se constroem com a força da autoridade divina através de atos de fala performativos: "Tocou o féretro"; "Jovem, falo contigo"; "Levanta-te". Como em outros milagres, a palavra de Jesus tem a força ilocutória e gera um ato performativo. No caso em questão, sobretudo, quando o Senhor quer transformar a vida social dos excluídos (viúvas e órfãos) como já o era no Antigo Testamento.. Como diz o salmista $(68,6)$, Jesus é o pai de órfãos e protetor das viúvas.

5- Jesus em casa de Simão: "E disse a ela: - Teus pecados te são perdoados. Tua fé te salvou. Vai em paz."

Jesus pronuncia a fórmula da absolvição, sancionando a reconciliação, assim como o fazem os ministros da Igreja. (A todos aqueles a quem perdoardes os pecados ser-lhesão perdoados). A força do ato Ilocutório é tão grande que não só perdoa mas também 
provoca escândalo entre os convidados. Por outro lado, a fórmula "Vai em paz", além de fórmula de despedida passou a ser, a da prática cristã: da penitência e da eucaristia.

6- "Ao pôr os pés em terra saiu-lhe ao encontro um homem da cidade, endemoninhado. (...) Ao ver Jesus, deu um grito, lançou-se diante dele e disse gritando: - Que tens comigo, Filho de Deus Altíssimo? Eu te suplico que não me atormentes."

Obs: O pedido do endemonhiado "Eu te suplico não mais me atormentes" recebe pronta resposta de Jesus através do ato performativo. As palavras de Jesus não são apenas um ato comunicativo. São verdadeiras ações como queria Vittgenstein. Mandava que o espírito imundo saísse daquele homem, pois muitas vezes se apoderava dele. Cristo praticou o exorcismo através de um ato performativo.

7- “Num sábado, estava ensinando numa sinagoga, quando se apresentou uma mulher que há dezoito anos padecia de um espírito (...) Ao vê-la, Jesus a chamou e lhe disse: - Mulher, estás livre de tua doença. Impôs-lhe as mãos. E, no mesmo instante, ela se endireitou e dava glória a Deus. (Lc 13, 10-14)

Obs: Ao dizer "Estás livre de tua doença" e "Impôs-lhe as mãos", realiza-se a ação de curar, confirmando o que dizia Austin: Dizer é fazer.

8- Em Betânia, Jesus ressuscita Lázaro, seu amigo e irmão de Marta e Maria. Jesus deu graças ao Pai e gritou com voz forte: "Lázaro, vem para fora." O morto saiu com os pés e as mãos atados, com vendas e o rosto num sudário." Aí está o fato de que atos de fala, em sua maioria, tornam ação. O dizer é fazer.

9- Na última ceia, diz o evangelho de João (J0 13, 4-5): “Jesus põe água numa bacia e começa a lavar os pés dos discípulos e a secá-los com a toalha que tinha cingido."

\section{CONCLUSÃO}

A teoria dos atos de fala surgiu no interior da filosofia da linguagem, no início dos anos sessenta e assumida por Austin e os seguidores de Wittgenstein na Pragmática. Para Searle e outros, os atos de fala são uma forma de ação “(Dizer é fazer). O corpo da teoria surgiu com as doze conferências proferidas por Austin na Universidade de Harvard, EUA, em 1955 e, posteriormente publicado em 1962. Ideia básica: How to do 
things with words. Dizer não é só transmitir informações mas é sobretudo uma forma de agir sobre o interlocutor e sobre o mundo.

Este estudo está estruturado nos conceitos, autores e origens da teoria dos atos de fala. Mais particularmente com aplicação em 9 passagens dos evangelhos, cujo papel de Cristo destaca suas ações de cura. Em cada um dos exemplos apresentados, destacase $\mathrm{o}$ ato de fala de base performativa nas palavras de Jesus. A consequência de cada um é o ato de cura implícito no significado das palavras actanciais.

\footnotetext{
i Utilizamos aqui e em todo este trabalho o termo "sentença" no lugar de "proposição".

ii Wilson, Victoria. Motivações pragmáticas. In Manual de linguística. Mario Eduardo Martelotta. S. Paulo: Contexto, 2008, p 88-92

iii Note-se que há casos de performativos implícitos em que pedidos, promessas, ameaças, reclamações não nsão indicados por verbos coprrespondentes a ações. Um exemplo claro de ato performativo está numa frase sem verbo: "Promessa é dívida”.Por outro lado, há performativos puros, como "Eu te batizo. "Eu te benzo, eu te curo." "Prometo que vou ao teu aniversário."

iv Searle, John R. A classification os illocutionary acts. Language in Society, $n$. 5. Londres: Cambridge University Press, 1976, p1-2,3.
} 


\section{REFERÊNCIAS BIBLIOGRÁFICAS}

SAUSSURE, Ferdinand de. Curso de linguística geral. S. Paulo: Cultrix/Edusp, 1969. MARCONDES, Danilo. As armadilhas da linguagem: significado e ação para além do discurso. Rio: Objetiva, 2017.

AUSTIN, John L. How to do things with words. New York: New York Press, 1965

SEARLE, John R. Expression and meaning. Cambridge: Cambridge University Press, 1979.

SEARLE, John R. A classification of illocutionary acts. Language in Society, n. 5. Londres: Cambridge University Press, 1976.

SCHÖKEL, Luís Alonso. Bíblia do peregrino. S. Paulo: Paulus, 2000

FIORIN, José Luiz. Linguística? Que é linguística? S.Paulo: Ed. Contexto, 2017

MARTELOTTA, Mario Eduardo (Org) et al. Manual de Linguística. S. Paulo: Ed.

Contexto, 2008

BORBA, F. da Silva. Introdução aos estudos linguísticos. S. Paulo: Ed Pontes, 1991.

PLATÃO. Crátilo. Diálogo sobre a justeza dos nomes. Lisboa: Livraria Sá da Costa: 1994 